\title{
Determinants of Audit Fees : Evidence from UK Alternative Investment Market
}

\author{
Nishtiman Hashim Mohammed ${ }^{1}$, Abdullah Saeed Barwari² \\ ${ }^{1}$ University of Duhok- College of Administration and Economic, Duhok, Kurdistan Region - Iraq \\ ${ }^{2}$ Duhok Technical Institute-Duhok Polytechnic University, Duhok, Kurdistan Region - Iraq
}

\begin{abstract}
The main purpose of this study is to examine the determinants of audit fees in the Alternative Investment Market (AIM) using a sample of 23 machinery equipment companies covering the period from 2007 to 2011. The factors that have been hypothesized to be having a significant correlation with audit fees are auditee size, auditee complexity, audit risk, and auditor size. The results show that auditee size and auditee complexity are the main significant determinants of audit fees in the AIM. The findings also indicated a positive relationship between audit timing and audit fees. However, there was not significant evidence of a positive correlation between auditee risk and audit fees, which demonstrated that risk perceived by the auditor does not affect the value of fees. The results also indicated that there is no difference in the fees value between large or small clients. Moreover, the study demonstrated that there is no correlation between providing non-audit service and audit fees. Therefore, it is believed that the differences of these results with other studies in this field are due to the differences in the regulatory framework of the market selected as a sample for this study.
\end{abstract}

KEYWORDS : Audit fees, Auditee size, Auditee complexity, Non-audit fees.

\section{The Theoretical Part 1. INTRODUCTION}

The foundations of the auditing profession stretch back to an early time in world history. Records of auditing activities have been found from Babylonian times (around 3,000 BC) and from ancient China. At those times, auditors in China were supervisors of the accounts of the Zhoa Dynasty and they were supervisors of the accounts of the Egyptian pharaohs in Egypt (Rick, Dassen, Schilder, \& Wallage, 2005). Auditing was also exercised in ancient Greece and Rome; the terms of "hearer or listener" were used in Latin to refer to the "auditor", as reports in Rome about the business results of the taxpayers were heard by the auditors (Willmott, 1986). The auditing profession, as any industry, was developed and affected by the growth in the economy and related industries. Particularly, the need for more auditing practice in society increased in the $18^{\text {th }}$ century, after the Industrial

Academic Journal of Nawroz University

(AJNU) Volume 7, No 3 (2018).

Received 22 Feb 2018;

Regular research paper : Published 20 June 2018

Corresponding author's e-mail : nishtimanmohammed87@gmail.com

Copyright (C2018 Nishtiman Hashim Mohammed.

This is an open access article distributed under the Creative

Commons Attribution License.
Revolution and companies' expansion in the age of globalization $(\mathrm{Vu}, 2012)$. One important area of concern that was created as a result of globalization and market development is the separation between the ownership (shareholders) and management (agents) (Rick et al., 2005). This separation is known as agency theory, which implies that owners are placing their trust in the hands of management to run their business and that they hope that management is acting in their best interests, that is, to increase the shareholders' wealth (Kasim, 2005). However, the owner-agent relationship could be damaged when the management fails to achieve the goal of the shareholders once they act in their own best interests (Rezaee, 2009). This is often referred to as agency problem, as there are three agency costs; however, the only interest in this study is in the monitoring cost that is related to the monitoring of the agent's behaviour (Jensen \& Meckling, 1976). Hence, companies are subject to an annual statutory audit that functions to ensure that the company has efficient policies and procedures in place to look after the interests of the owners and to add value to the reliability of the financial statements (Kasim, 2005). The auditor, therefore, is needed to check whether the financial statements are prepared in accordance with the public accounting standards. They are also needed to ensure that the financial statements are free from material misstatements that may mislead the owners and other users of the financial statements (Millichamp 
\& Taylor, 2008). Due to the corporate scandals at the start of the 21 $1^{\text {st }}$ century, such as Enron and Worldcom in the United States (US), and Parmalat in Europe, there has been a change of public belief about the auditor's morals and role in society $(\mathrm{Vu}, 2012)$. This is because some audit firms have fallen into disrepute and question marks have been placed over the auditors' independence, competence and the obvious failures of corporate governance (Millichamp \& Taylor, 2008). Hence, among the factors that impact on the independency of the auditor is the audit fees. The association between auditor independence and audit fees comes from the public belief that auditor independence is damaged when the auditor charges the client abnormal audit fees (Millichamp \& Taylor, 2008). Audit fees is considered to be one of the crucial issues within the literature in recent years due to its correlation with auditor independence. It has been suggested that the auditor's independence is damaged when they 'lowball' by providing services to clients at a low fee. An early study by De Angelo (1981 : p113) defined lowballing as "setting audit fees below total current costs on initial audit engagements". The audit firms use lowballing as a strategy in a competitive audit market to obtain more clients by providing competitive audit fees. Hence, Millichamp and Taylor (2008) stated that under certain circumstances there is an existing link between auditor independence and audit fees. For this reason, understanding the determinants of audit fees, the main focus of this study, is important for the clients and the suppliers of audit services (Che-Ahmad, Houghton, \& Zalina Mohamad Yusof, 2006; Kasim, 2005). Moreover, audit fee determinants are significant for market regulators to highlight whether the audit services are priced competitively, as this could impair the audit's independence and quality (Che-Ahmad et al., 2006). To this end, selecting the audit fees as a topic for this research derived from the considerable discussion in the literature about audit fees. The study provides new evidence from the United Kingdom (UK) as it presents information about external audit fees in the Alternative Investment Market (AIM). Accordingly, it is worth examining the relationship between the audit fees and the factors determining audit fees. The main aim of this study is to provide new evidence on the determinants of audit fees in the UK. Particularly, the purpose of this study is to investigate the factors that have an effect on determining audit fees for a number of companies listed on the AIM. Many studies have been conducted on the determinants of audit fees in the UK, although most of these studies employed data from the main markets, such as (Chan, Ezzamel, \& Gwilliam, 1993; Che-Ahmad \& Houghton, 1996; C. M. Pong \& Whittington, 1994). Moreover, several studies have examined the determinants of audit fees in the UK for charities (Beattie \& Fearnley, 2002), the university sector (Abidin, Beattie, \& Goodacre, 2010), and for the National Health Service (M. Clatworthy, Mellett, \& Peel, 2000). To date, there has not been substantial work on audit quality, auditor independence, or the determinants of audit fees in the AIM (Clatworthy \& Peel, 2007). Hence, this study provides a closer examination of the determinants of audit fees in the AIM. The AIM was introduced by the London Stock Exchange (LSE) in the UK in 1995 as a means to benefit small and medium-sized companies by being listed companies (Mallin \& Ow-Yong, 2012). The AIM, as a second market, has fewer requirements to list the companies than those requirements needed for listing companies on the main markets. The regularity environment of the AIM is designed to meet the needs and requirements of small companies. For example, the AIM does not stipulate a minimum company size or the number of shareholders (Colombelli, 2010). Therefore, the AIM includes smaller and higher risk companies that are not able to access capital funds without obtaining full listing status with the LSE (Cohen, Gaynor, Krishnamoorthy, \& Wright, 2007). Since its creation, the number of companies listed on the AIM reached over 1,200 companies in 2010 (Mallin \& OwYong, 2012), as the flexible regularity framework of the AIM has attracted many local and international companies to join this market.

\section{Prior Literature and Hypotheses Development : \\ 2.1 Audit fees}

The amount of audit fees is often determined before conducting the audit process, and the audit fee is suggested to be fair when compared with the potential effort that the auditor spends, such as in the audit procedures and through the time required (AlMatarneh, 2012). Subsequently, an important question is raised regarding the audit fees' calculation in the UK : how much do they charge the clients? In the UK, the most common type of basis for charging audit is the hours base (ICAEW, 2012). In the UK, the most common type of basis for charging audit is the hours base (ICAEW, 2012). The Institute of Chartered Accountants in England and Wales (Willmott, 1986 : 127), in a report about the auditing futures, states that:

There are no standard rates of charges for professional work; it is up to each practitioner to set his/her own scale of charge. If you charge too much, you will lose your clients, who will take their business to your competitors. If you charge too little, you will end up in poverty. Therefore, in the UK there is no standard rate of charge for the audit service. The most successful audit firm is one which accepts clients that have the ability to pay a fair value for the audit services. Besides, providing a competitive audit service is a good feature to attract a large number of clients, although a cheap 
audit service leads to a decrease in turnover, which subsequently causes the inability of the audit firm to provide training in order to improve the audit quality (Willmott, 1986).

\subsection{Auditee Size :}

Auditee size represents an effective factor that has an important role in the audit process. Most of the previous studies confirmed the importance of the size of client firm on determining audit fees (Rick et al., 2005). According to Alexeyeva (2012), large auditee size requires more time and effort to undertake the audit procedures than smaller auditee firms. For instance, large auditee size requires more time to investigate much more complicated financial transactions and to test a large number of balances. In addition, the auditor might be required to evaluate a complicated internal control system and hold more meetings with the client's employees in large auditee firms (Beattie \& Fearnley, 2002). The auditors in large client firms may feature stronger internal control systems than smaller firms. The auditors reduce the audit processes or design a small audit procedure and appoint a small audit sample for firms that have an adequate internal control system in place $(\mathrm{Vu}, 2012)$. According to a study conducted by Ahmed and Goyal (2005), the size of auditee was related to the decentralisation, and as firms became bigger, the problem of information asymmetry was severe; therefore, they argued that "the contracting constituents in large firms may demand greater monitoring and control from auditing and hence incur higher costs than small firms to resolve their agency problems" (Willmott, 1986 : 107). From this point of view, auditee size is considered one of the significant factors in determining audit fees. In an early study in 1980, Dopuch and Simunic (1980) provided evidence that the auditee firm size was a strong factor that had a direct impact on determining audit fees. Following that, several studies obtained evidence regarding the audit client size. Hogan and Jeter (1999), for example, examined the determinants of audit fees in the energy sector and his results indicated that the auditee firm size was positively related to audit fees. Moreover, the majority of the studies conducted in the UK found that auditee firm size was a significant variable in determining audit fees (Chan, Lin, \& Zhang, 2007; P. Chan et al., 1993; Mellett, Peel, \& Karbhari, 2007). Furthermore, using a sample of 126 non-financial firms listed on the Copenhagen Stock Exchange in 2002, Thinggaard and Kiertzner (2008) examined the factors that impact determining audit fees in Denmark. They found a positive correlation between auditee firm size and audit fees. However, an Australian study by Carson and Fargher (2007) attempted to examine the audit fees' premium for the Big6 audit firms using data that covered a five year period from 1995 to 1999 . The study was limited to the small and large client segments in the audit markets. The authors found that the linear relationship did not exist between auditee firm size and audit fees. This means that audit fee is unlikely to increase with large auditee size. Sandra and Patrick (1993) provided a justification for the non-linear correlation between auditee size and audit fees. They stated that large companies might have sophisticated internal control procedures in place that help to reduce the audit work. In short, the majority of the previous studies provided evidence suggesting that there was a positive correlation between auditee size and audit fees; hence, the current study generates the following hypothesis :

H1 : The audit fee has a positive relationship with auditee size.

\subsection{Auditee Complexity :}

Complexity of the client firm is another factor that has been used to illustrate the variation of audit fees. This is because companies differ from one another in terms of their diversification in foreign business operations (Davison, Stening, \& Wai, 1984; Kasim, 2005). Logically, it is believed that organisations that have a large number of subsidiaries and foreign operations are more complex for the auditors than organisations with a small number of subsidiaries. That is due to the fact that the complex firms require more audit work and hence charge greater audit fees (Joshi \& Al-Bastaki, 2000). Moreover, different levels of complexity require different audit tasks regarding the time spent in the audit process or the effort required in investigating the organisation's transactions, as well as evaluating the internal control system $(\mathrm{Vu}, 2012)$. Sandra and Patrick (1993) reported that one of the reasons why firms with a large number of subsidiaries are paying higher audit fees is that the subsidiaries in different countries complied with the statutory requirements of disclosure in each country. Thus, the differentiation in statutory requirements creates a need for further audit testing, which leads to increased audit fees. Various studies have been conducted in different countries that have investigated the importance of auditee complexity as one of the determinants of audit fees, and these have found mixed results. Some studies have found a positive relationship between auditee complexity and audit fees. Brinn, Peel, and Roberts (1992) examined the determinants of external audit fees, focusing on a sample of 154 companies in the electronics sector in the UK for the year 1988. They found that one of the key determinants of audit fees was auditee complexity, in which it had a positive correlation with audit fees. In addition, Joshi and Al-Bastaki (2000), Thinggaard and Kiertzner (2008) and Xu (2011) measured auditee complexity by the number of subsidiaries in foreign countries. They found a positive association between 
the number of foreign subsidiaries that reflects auditee complexity and audit fees. This is because the external auditors spent more time and effort examining the accuracy of the consolidated financial statements, which included a number of subsidiaries' work in foreign countries in which they were subjected to the policies and accounting standards of those countries. However, a study by Kasim (2005) investigated the factors affecting the variation of audit fees in Malaysia did not find strong evidence of the impact of auditee complexity on audit fees. Moreover Vu (2012) who investigated audit fees' determinants in data from Swedish non-financially listed companies for the year 2010, did not find accurate evidence on the correlation between auditee complexity measured by the nature of the firm's assets and audit fees. Furthermore, a study by Zhang and Myrteza (1996) indicated that there was a negative correlation between audit complexity and variation of the audit fees. To sum up, a review of the prior literature shows that most of the studies obtained evidence regarding a positive correlation between auditee complexity and the variation of audit fees. Based on these results, the current study assumes the following hypothesis :

H2 : The audit fee has a positive relationship with auditee complexity.

\subsection{Auditee Risk :}

Auditee risk is defined as "the risk that an auditor may express an inappropriate opinion on financial information that is materially misstated" (Soltani, 2007 : 216). Previous studies have suggested that audit risk can be used to determine audit fees. According to Pong and Whittington (1994) and Xu (2011) audit firms might be exposed to a legal liability or loss of reputation from a high level of client audit risk. Therefore, research has addressed audit risk as one of the factors that affects the determination of audit fees. An example of the importance of auditee risk on the variation of audit fees was examined by Zhang and Myrteza (1996) in a sample of 243 Australian listed companies. The authors found that within the financially distressed companies, auditors spent more time to find relevant evidence in the audit process; therefore, they charged more fees. In this regard, a number of studies from different countries have found various results. On one hand, studies suggest that the auditee risk can have a significant impact on audit fees. For example, Joshi and Al-Bastaki (2000) investigated the effect of audit risk on audit fees by examining the structure of audit fees for 38 companies listed on the Bahrain Stock Exchange. The authors confirmed that there was a significant positive correlation between audit risk and audit fees. In another study, Hogan and Jeter (1999) provided insightful evidence of the audit fees paid by the energy sector and the factors determining audit fees by examining a sample of 120 firms. After analysis, he found that companies that had high indicators of net loss or higher leverage paid higher audit fees than companies with lower leverage and net loss indicators. In a different national context, a study by Pong, Gonthier-Besacier, and Schatt (2007) investigated the factors that influenced the determination of audit fees in France, since companies had started the disclosure of audit fees in their financial reports from 2002. The findings of this study show that audit risk has a positive significant relationship with audit fees; hence, they argued that one of the factors that determine audit fees in France is auditee risk. On the other hand, other studies found that there was no evidence of a significant association between the audit risk and audit fees. An empirical Chinese study by $\mathrm{Xu}$ (2011) investigated the factors which determine the audit fees by employing data from 191 listed companies in China. The research results indicated that there was no significant impact of audit risk on audit fees' determination. Moreover, Vu (2012) suggested that there was no precise answer for the association of audit risk on audit fees. It is worth noticing through reviewing the findings of prior studies that there are mixed results for the association between the audit risk and audit fees. The majority of the studies found that there was a positive relationship between the audit risk and audit fees; hence, the hypothesis will be : H3 : The audit fee has a positive correlation with auditee risk.

\subsection{Audit Timing :}

As a matter of fact, the majority of the publicly traded companies have the same financial year-end date. Typically, the fiscal year-end date of the companies is the $31^{\text {st }}$ of December each year, when most companies' financial accounts are audited. The period of the financial year-end creates a condition for the auditors known as the 'busy season' (López \& Peters, 2011). In this busy season, the resources of the audit firms reach their limits, which causes extended daily work for the auditors. Particularly, the auditors whose are working as employees in big audit firms are obliged to work overtime each day $(\mathrm{Vu}, 2012)$. Hence, the auditors expect to receive higher fees than the regular standard rates during the busy season. From this point of view, the busy season plays an important role in the variation of audit fees. (Whittred \& Zimmer, $1984: 80$ ) referred to the audit timing as "the natural log of days from financial year end to the date of auditor signature". The importance of this factor comes from the thought that the auditors' performance and behaviour might be affected by the pressure of demands for the audit services during the busy season (López \& Peters, 2011; Sweeney \& Summers, 2002). Studies in different countries have focused on examining the relationship between the audit busy season and audit fees. A 
number of studies have found a positive relationship between audit fees and audit timing. An Australian study by Zhang and Myrteza (1996) focused on investigating the workload required to complete the audit service for a number of Australian listed companies from 1990 to 1992 . They found that there is a positive relationship between audit timing and audit fees. Furthermore, Sandra and Patrick (1993), who analysed data from Hong Kong, found a significant positive relationship between audit timing and audit fees. However, studies by Joshi and Al-Bastaki (2000) and Kasim (2005) that analysed Bahrain and Malaysia's business environments, respectively, predicted to find a positive association between audit fees and the client's financial year-end during the peak season. Nevertheless, the results did not show evidence of a positive relationship between audit fees and audit timing and they considered audit timing as an insignificant factor in determining the audit fees. Studies conducted in the UK such as Chan et al. (1993) and Pong (2004) sought to examine the link between audit timing and audit fees. However, the statistical results of both studies indicated that the effect of audit timing and audit fees was not significant. Thus, the current study assumes the following hypothesis :

$\mathrm{H} 4$ : The audit fee is associated with audit timing.

\subsection{Auditor Size :}

Audit firms differ from each other in terms of their size. The importance of auditor size or audit brand name comes from the suggestion that auditor reputation reflects high audit quality (Sandra \& Patrick, 1993). Therefore, the large audit firm size can provide high audit quality to the auditee insofar as it possesses a strong reputation which leads it to increase the audit price. A number of studies obtained evidence regarding the high premium paid to the big audit firms such as the (Big8/ 7/ 6/ 5/ and now Big4). According to an early study by Francis (1984) : 134), "the effect of audit firm size on audit prices is a complex function of competition in the market for audit services, product differentiation, and scale economics to large firms". A number of studies sought to examine the effect of auditor firm size on audit fees. Dopuch and Simunic (1980) classified the audit firms into two segments of "Big8" and "Non-Big8", and his goal of such classification was to separate the market into two segments : a large number of small audit suppliers and the Big8 audit firms. Simunic suggested that the segment with the large number of audit firms led to increased competition among firms and vice versa. He expected to find price differences between both segments; however, the results were not significant. The explanation that Dopuch and Simunic (1980 : 188) gave for his findings was that "the Big Eight firms enjoy scale economies which are passed on as lower prices to auditee". In contrast, Francis (2004) found that the large audit firms or the Big4 provide higher levels of quality compared to the Non-Big 4 firms. He argued that "it's not high-quality auditing that causes the observed audit outcomes; rather, auditor choice is endogenous and it may simply be that good firms with good earnings quality hire high-quality auditors" (Willmott, 1986 : 354). This means that companies that desire to acquire high audit quality are more likely to deal with the Big4; hence, audit fees charged by the Big4 are dissimilar in comparison to the audit fees charged by the Non-Big4. Consistent with high audit quality, studies by Gist (1992) and Simon and Francis (1988) obtained evidence that confirmed a positive correlation between auditor size and audit fees. A study by Behn, Choi, and Kang (2008) focused on investigating the effect of the size of a local office audit on audit quality and audit fees using variables such as unsigned abnormal accrual as a proxy for audit quality. The study indicated a positive correlation between the auditor size in both audit quality and audit fees. The authors' explanation for their results was that large audit firms often have large numbers of clients and so the auditor has more options, rather than concentrating on a specific client. However, studies by Al-Harshani (2008) and Che-Ahmad \& Houghton (1996) were unsuccessful in finding clear evidence for the relationship between auditor size and audit fees. In short, this review of the studies shows that the majority of the studies support the high audit quality of the Big4 and a positive correlation between auditor size and audit fees. Thus, according to the findings of the literature, the hypothesis for this variable will be :

H5 : The audit fee has a positive relationship with auditor size.

\subsection{Non-Audit Fees :}

The non-audit services consist of any other consultancy services that the external auditors are able to provide to the clients besides the audit services. The auditors are able by law to provide the non-audit services to the clients as long as those services fall within the scope of the auditor's work, and also since the auditors do not hold any management responsibility as a result of those services (Thinggaard \& Kiertzner, 2008). In recent years, the audit and accounting literature has focused on evaluating the impact of the non-audit service on audit quality, in particular after the corporate scandals of Enron, Worldcom and the introduction of the SarbanesOxley Act (SOX) in the US in 2002 (Vu, 2012).

Researchers have suggested that providing non-audit services by the same audit firm that provides the audit services might lead to 'knowledge spillovers'. An early study by Simunic (1984) used audit service and management advisory services or the non-audit service to determine knowledge spillovers by analysing a 
sample of 397 US listed companies. He argued that if a client purchased both audit and non-audit services from the same auditor, and the auditor reduced the level of fees charged for the client, that the client would then continue with the same audit firm. Simunic (1984) results show that the clients who purchased both audit and non-audit services from the same auditor paid higher fees than the clients who purchased the services from different audit firms. Subsequent studies by Davis, Ricchiute, and Trompeter (1993) and Palmrose (1986) conducted further investigations into the relationship between audit and non-audit fees in the US. Palmrose (1986) included in her study all the non-audit services such as tax, accounting related to management advisory services and accounting not related to management accounting services. However, Davis et al. (1993) used audit hours as a proxy to test whether there were knowledge spillovers or not. The results of both Davis et al. (1993) and Palmrose (1986) studies showed a positive correlation between audit and non-audit fees, which is consistent with the results of (Simunic, 1984). In addition, studies by Barkess and Simnett (1994) and Chan et al. (1993) in Australia and the UK, respectively, tested whether there was a positive or negative correlation between audit fees and non-audit fees in each market. The findings indicated a positive correlation between the expenditures of the audit and non-audit services. Firth (2002) study explained that the reasons for the positive correlation between audit and non-audit fees was the demand for the consultancy service by the companies, particularly in special events such as mergers and acquisitions, change in management, new finance, and restructuring. Hay, Knechel, and Wong (2006), Whisenant, Sankaraguruswamy, and Raghunandan (2003) also proved that there were no knowledge spillovers through their investigation between audit and nonaudit services. However, a study by Abdel-Khalik (1990) suggested that the audit client would be paid a lower cost if a single auditor supplied both the services, than each service being supplied by different audit firms; Abdel-Khalik's results were consistent with his argument. Clatworthy, Mellett, and Peel (2002) on the other hand, examined the relationship between audit and non-audit fees in the UK's National Health Service sector, and they found that providing non-audit services affected audit fees negatively due to knowledge spillovers. Therefore, the present research sets the following hypothesis :

H6 : The audit fee has association with non-audit fees.

3. Methodology :

3.1 Sample :

The population of the UK companies listed on AIM was chosen to represent the sample for this study. The initial sample included 866 UK listed companies from different sectors that were available on the LSE. However, the available data via the Financial Analysis Made Easy (FAME), included data from 836 companies. Since companies listed on the AIM almost have the same criteria, all of them had an equal chance of being chosen in the sample for this study. Accordingly, the total population of companies was classified into 19 sectors, and from this sub-population one of the major sectors that had a large population of companies was selected as the sample for the current study. The chosen sector with the largest population was machinery equipment, which included 67 companies. Data for this sector were available for only 23 companies.

\subsection{Secondary Data :}

The current study used documentary secondary data in the form of written documents that comprised the existing annual reports of the companies chosen and their analysis in order to answer the research questions. The main reasons for using secondary data for this research were to save time and costs that are significant considerations in the data collection process. Data for the current study covers the period from 2007 to 2011.

\subsection{Data Analysis :}

Following Chan et al. (1993), Joshi and Al-Bastaki (2000) and Van Caneghem (2010) the techniques employed in this study to analyses the data were the bivariate test and the multiple linear regression that were analyzed through the SPSS program. The main purpose of using a simple correlation is to measure the degree of association between two variables (Berenson, Levine, Szabat, \& Krehbiel, 2012). Meanwhile, the purpose of using multiple linear regression in the current study was to predict audit fees through the association between auditee size, auditee risk, auditee complexity, auditor size, non-audit fees, and audit timing. To achieve this aim, the audit fees model has been developed in this study following the studies of Naser and Nuseibeh (2008) and Simunic (1980) in order to examine the effect of the independent variables on the dependent variable. Assuming a linear correlation among the study's variables, the model of audit fees in this research is :

\begin{tabular}{|c|c|c|}
\hline \multicolumn{3}{|r|}{$\mathrm{JB}_{\mathrm{it}}+\mathrm{t}$} \\
\hline \multicolumn{3}{|c|}{$\beta_{4} \mathrm{LIQU}_{\mathrm{it}}+\beta_{5} \mathrm{GEAR}_{\mathrm{it}}+\beta_{6}$ LOSS $_{\mathrm{it}}+\beta_{7}$ NFEE $_{\mathrm{it}}+\beta_{8}$ Big 4 it } \\
\hline \multicolumn{3}{|c|}{$+\beta_{9} \mathrm{YEND}_{\text {it }}+\varepsilon_{\text {it. }}$} \\
\hline \multicolumn{3}{|l|}{ Where : } \\
\hline \multicolumn{3}{|c|}{ For each firm (i) and each year $(\mathrm{t})$} \\
\hline FEES $_{\text {it }}$ & $=$ & Audit fees \\
\hline TASS & $=$ & Total assets \\
\hline ARTA & $=$ & Account receivable/ Total assets \\
\hline NSUB & $=$ & Number of subsidiary \\
\hline LIQU & $=$ & Liquidity \\
\hline GEAR & $=$ & Gearing \\
\hline LOSS & $=$ & Company loss \\
\hline NFEE & $=$ & Non-audit fees \\
\hline
\end{tabular}




$\begin{array}{lll}\text { Big4 } & = & \text { Big4 audit firms } \\ \text { YEND } & = & \text { Financial year end } \\ \varepsilon_{\text {it }} & = & \text { Error term supposed to be }\end{array}$

normally scattered with constant differences

3.4 Measurement of the Study Variables :

This section is employed to illustrate how the variables were measured in this study and the proxy allocated for each of the variables.

\subsubsection{Audit Fees :}

The dependent variable in the context of this study is the audit fees, which refers to the amount of fees paid to the external auditors for the auditing service. Following (Pong et al., 2007; Pong, 2004; Simunic, 1980) adopted the same approach regarding the audit fees. In those studies, audit fees represented the fees disclosed in the company's income statement that reflected the total amount of fees paid for auditing the annual reports and consolidated accounts of the parent companies.

\subsubsection{Auditee Size :}

The current study followed the study of Ahmed and Goyal (2005) and employed total assets as a proxy to measure auditee size. Data about the total assets were collected from the company's annual reports, particularly from the balance sheet covering the period 2007-2011.

\subsubsection{Auditee Complexity :}

Auditee complexity in the context of this study refers to the degree of the audit task. This study followed the measurement approach adopted by (Joshi \& Al-Bastaki, 2000; Sandra \& Patrick, 1993) to measure auditee complexity. These approaches account receivable to total assets, and the number of subsidiaries. All information about the measurements of auditee complexity was available in the annual reports of the thirteen companies chosen as a sample for this study.

3.4.4 Auditee Risk :

Several studies have used a number of proxies to measure risk (Joshi \& Al-Bastaki, 2000; Pong et al., 2007) such as profitability through Return on Equity (ROE), qualified-unqualified opinion, liquidity ratio, gearing ratio, company's loss, and debt scaled by the total assets. This study relies on the measurements used by prior studies, namely, liquidity ratio, gearing ratio, and company loss as a proxy of audit risk. The study follows the research of Pong et al. (2007) regarding the company loss and assumes that if the companies chosen as a sample made loss at least once over the last 5 years, they were given a value of 1 . Otherwise, a value of zero was given to companies that were not making a loss.

\subsubsection{Non-Audit Fees :}

In the annual reports of UK listed companies on the AIM, fees paid to the auditor are classified into audit fees and non-audit fees. The non-audit fee is measured in thousands of pounds and includes tax advice, nontax advisory services, other auditor services, and nonaudit fees paid to other auditors. Data about non-audit fees is detailed in the chosen companies' financial reports, namely, the income statements over the period of this research which covers 2007 to 2011.

\subsubsection{Auditor Size :}

This study followed the Big4's approach to dividing audit firms into two groups, in which a value of zero was given to companies audited by Non-Big4 audit firms and a value of 1 was given to companies audited by the Big4. This approach was adopted by (CheAhmad \& Houghton, 1996; Choi, Kim, \& Zang, 2010; Simunic, 1980). Figure (3.1) shows the study framework. 3.4.7 Audit Timing :

The year-end for the majority of UK companies listed in the AIM is $31^{\text {st }}$ December, while they report about their operations at different times of the year, especially on $31^{\text {st }}$ March. Hence, in the literature this period is recognized as a busy season and it is used as a variable to measure the effect of audit timing on audit fees (Pong, 2004). In addition, the lag between the audit report and the end of the accounting year is another variable that has been used by previous studies to measure the variations of audit fees (Chan et al., 1993). This variable is measured in terms of the number of weeks between the company's ending year and the date of issuing its audit report. Thus, the study has adopted the same approach of Pong et al. (2007) in measuring audit time, in which a value zero was given to companies if their financial year was not $31^{\text {st }}$ December; otherwise, a value of 1 was given to companies ending their financial year on $31^{\text {st }}$ December.

\section{Empirical Results :}

4.1 Descriptive Statistics :

The descriptive statistics employed in this study are the mean, standard deviations, and the minimum and maximum values for the variables. Table (4.1) shows the descriptive statistics of the study. 
Table (4.1) : Descriptive Statistics

\begin{tabular}{|c|c|c|c|c|}
\hline Variables & Minimum & Maximum & Mean & Std. Deviation \\
\hline FEES & $£ 13,000$ & $£ 178,000$ & $£ 58,687$ & $£ 39,036$ \\
\hline TASS & $2,240,000$ & $198,892,000$ & $29,380,104$ & $26,833,981$ \\
\hline ARTA & 3 & 41 & 17.63 & 7.45 \\
\hline NSUB & 1 & 60 & 11.78 & 14.13 \\
\hline LIQU & 0.27 & 4.17 & 1.63 & 1.02 \\
\hline GEAR & 0.31 & 211.30 & $35.30 \%$ & 33.74 \\
\hline LOSS & 0 & 1 & $52.17 \%$ & $50.17 \%$ \\
\hline NFEE & $£ 2,000$ & $£ 278,000$ & $£ 41,765$ & $£ 49,130$ \\
\hline Big4 & 0 & 1 & $34.78 \%$ & $47.83 \%$ \\
\hline YEND & 0 & 1 & $30.43 \%$ & $46.21 \%$ \\
\hline
\end{tabular}

It clearly can be seen from the table above that the mean of the audit fee is $£ 58,687$, which is greater than the standard deviation of $£ 39,036$. Generally, this might be a signal that the variation of audit fees is rather less. The range of the variation of audit fee is between a minimum of $£ 13,000$ and a maximum of $£ 178,000$, which can be explained by the fact that there is a large gap between the companies in terms of the amount of audit fees. This is in line with the results of (Clatworthy \& Peel, 2007; Naser \& Nuseibeh, 2008), who found a large range between the minimum and maximum values of audit fees. The mean of total assets, the proxy of auditee size, is $£ 29,380,104$, while the standard deviation is $£ 26,833,981$. The differences between the maximum and the minimum values appear to be large, with the maximum value being $£ 198,892,000$ and the minimum $£ 2,240,000$. Hence, the result shows that there is enough variation in auditee size among the machinery equipment companies. In the respect of auditee complexity, the mean of account receivable/total assets ratio is 17.63 and the standard deviation is 7.45 . Thus, the finding indicates that there is sufficient variation in auditee complexity in the AIM machinery equipment companies. Meanwhile, the results confirm that there are fewer variances in auditee risk among the AIM machinery equipment companies when risk is measured by gearing and liquidity ratio, and loss incurred in the last 5 years. The results are therefore consistent with the descriptive statistics of Sandra and Patrick (1993), who found that auditee risk did not seem to be high for the companies listed on the Hong Kong market. Furthermore, the result shows that the machinery equipment companies have large differences in terms of their non-audit fees. In the case of the Big4, the mean is $34.78 \%$, while the standard deviation is $47.83 \%$, which indicates that only 8 of the 23 machinery equipment companies have been audited by the Big4 auditing firms. This could be explained by there being enough variation in selecting the auditing firm among the machinery equipment companies. Moreover, when it comes to the company's year-end date, the mean is $30.43 \%$ and the standard deviation is $46.21 \%$. The result shows that 7 of the 23 companies in the study have their year-end date on $31^{\text {st }}$ December. This can illustrate that the variance in the year-end date or the busy season is sufficient among the AIM machinery equipment companies.

\subsection{Correlation}

Table (4.2) presents the correlation matrix between the study's variables. It can be seen from the table above that almost all the variables have statistical correlation with the audit fees $(\mathrm{P}<0.1)$, which means that these factors have influence on the variation of audit fees. Clearly, the correlation between the total assets, proxy of auditee size, and audit fees is 0.722, indicating a significant positive relationship. Hence, audit firm size represents a significant factor to explain the variation of audit fees. In addition, number of subsidiaries, account receivable/total assets ratio, gearing ratio, non-audit fees, Big4, and year-end date are positively related to audit fees, in which the correlation coefficients are between 0.549 and 0.237 . 
Table (3) : Pearson correlation $(\mathrm{N}=724)$

\begin{tabular}{|c|c|c|c|c|c|c|c|c|c|c|c|}
\hline & FEES & TASS & NSUB & ARTA & LOQU & GEAR & NFEE & Big4 & YEND & $\begin{array}{c}\text { LOS } \\
\mathrm{S}\end{array}$ & VIF \\
\hline FEES & 1.0000 & & & & & & & & & & - \\
\hline TASS & $0.722^{* *}$ & 1.0000 & & & & & & & & & 2.17 \\
\hline NSUB & $0.545^{* *}$ & $0.618^{* *}$ & 1.000 & & & & & & & & 1.44 \\
\hline ARTA & $0.274^{* *}$ & 0.054 & $0.140^{\star *}$ & 1.000 & & & & & & & 1.17 \\
\hline LIQU & $-0.381^{* *}$ & $0.358^{* *}$ & $-0.342^{* *}$ & $0.102^{* *}$ & 1.000 & & & & & & 1.36 \\
\hline GEAR & $0.294^{* *}$ & $0.218^{* *}$ & $0.153^{* *}$ & $0.149^{* *}$ & $-0.414^{* *}$ & 1.000 & & & & & 1.56 \\
\hline NFEE & $0.549^{* *}$ & $0.658^{* *}$ & $0.457^{* *}$ & 0.012 & $-0.155^{* *}$ & $0.143^{* *}$ & 1.000 & & & & 1.70 \\
\hline Big4 & $0.452^{* *}$ & $0.356^{* *}$ & 0.041 & -0.067 & $-0.142^{* *}$ & $0.457^{* *}$ & $\begin{array}{c}0.303^{*} \\
*\end{array}$ & 1.000 & & & 1.39 \\
\hline YEND & $0.237^{* *}$ & 0.087 & -0.014 & $0.121^{* *}$ & $0.179^{* *}$ & $0.196^{* *}$ & $\begin{array}{c}0.139^{*} \\
*\end{array}$ & $0.112^{* *}$ & 1.000 & & 1.17 \\
\hline LOSS & $-0.306^{* *}$ & -0.008 & -0.020 & $0.140^{* *}$ & $0.302^{* *}$ & 0.026 & -0.017 & $-0.215^{* *}$ & $-0.123^{* *}$ & 1.00 & 1.22 \\
\hline
\end{tabular}

However, negative correlations were found for two other variables, namely liquidity ratio and loss incurred in the last 5 years. The correlation coefficients for those variables are -0.381 and -0.306 , respectively. Yet, it is important to note that none of the variables employed for the current study showed non-association with audit fees. Furthermore, the correlation matrix among the study variables shown in Table (4.2) indicates a multicollinearity problem that appears from the relationship between two or more of the independent variables that are related to each other. The variable of total assets, for example, has associations with another five independent variables; although it has only three strong relationships with non-audit fees at 0.658, number of the company's subsidiaries at 0.618 , and the Big4 at 0.356. Therefore, to deal with the multicollinearity problem and avoid misleading due to the strong relationships between the independent variables, the study will use a diagnostic procedure through checking the value of the Variance Inflation Factor (VIF). Regarding the multicollinearity problem, Gujarati and Porter (2003) argued that since the correlation value did not exceed 0.80, the multicollinearity problem was not important. Neter, Wasserman, and Whitmore (1993), on the other hand, reported that since the value of VIF was below 10, the multicollinearity problem was not considered a serious problem. Hence, the value of VIF was assumed to be below 2.5, which means that the multicollinearity problem in this study is not a serious problem. The results of the multiple linear regression do not indicate any multicollinearity problem, since the values of VIF were less than 2.5 .

\subsection{Multiple Linear Regression :}

Multiple linear regression (R) was used in this study for the analysis. The aim of using this technique was to forecast audit fees through the relationships between the independent variables. The square root of $\mathrm{R}$ was also calculated, while both $\mathrm{R}$ and the square root of $\mathrm{R}$ were used to measure how well the explanatory variables can determine the variation of audit fees. The value of $R$ is located between 0 and 1 , whereas the range of the square root of $\mathrm{R}$ is between 0 and $100 \%$ (Berenson et al., 2012). When the value of $R$ becomes bigger, this means that the independent variables are better able to predict the dependent variable. However, the independent variables do not have an effect on the dependent variable when the value of $R$ is equivalent to 0 , and the independent variables have a perfect prediction to the dependent variable when the value of $\mathrm{R}$ is equivalent to $1(\mathrm{Vu}, 2012)$. Furthermore, the adjusted $\mathrm{R}$ square is employed in order to identify how much change in the dependent variable can be explained by the research's independent variables. The results of the audit fees model and the multiple linear regression are illustrated in Table (4.3). 
Table (3.4) : Result of the Multiple Linear Regression

\begin{tabular}{|c|c|c|c|c|}
\hline \multirow[b]{2}{*}{ Item } & \multicolumn{4}{|c|}{ FEES Model } \\
\hline & 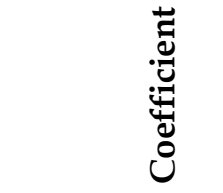 & 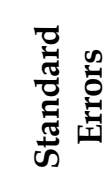 & $\frac{i}{2}$ & 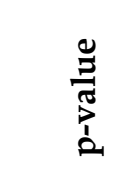 \\
\hline TASS & 0.001 & 0.528 & 8.106 & $0.000^{* * *}$ \\
\hline NSUB & 0.886 & 0.321 & 6.055 & $0.000^{* * *}$ \\
\hline ACTA & 0.785 & 0.251 & 3.132 & $0.002^{* *}$ \\
\hline LIQU & -3.787 & -0.099 & -1.922 & $0.057^{*}$ \\
\hline GEAR & 0.001 & 0.001 & 0.015 & 0.988 \\
\hline NFEE & -0.020 & -0.025 & -0.427 & 0.670 \\
\hline Big4 & 5.757 & 0.071 & 1.354 & 0.179 \\
\hline YEND & 10.386 & 0.123 & 2.566 & $0.012^{* *}$ \\
\hline LOSS & -16.322 & 0.123 & -4.294 & $0.000^{* * *}$ \\
\hline R Square & \multicolumn{4}{|l|}{0.795} \\
\hline Adjusted R Square & \multicolumn{4}{|l|}{0.778} \\
\hline $\mathrm{F}$ & \multicolumn{4}{|l|}{45.269} \\
\hline Sig. & \multicolumn{4}{|l|}{0.000} \\
\hline
\end{tabular}

Notes : ${ }^{*}=$ significant at $10 \%,{ }^{* *}=$ significant at $5 \%$ and ${ }^{* * *}=$ significant at $1 \%$.

The Sig $(\mathrm{P})$ of the audit fees model is 0.000 , meaning that the audit fees model is statistically significant. According to the results shown in Table (4.3), it appears that there are six independent variables that have a correlation with audit fees. Those variables are total assets by 0.000 , number of subsidiaries with 0.000 , account receivable/total assets 0.002 , liquidity ratio by 0.057 , year-end date 0.012 , and loss incurred in last 5 years at 0.000 . Four of the variables indicated a positive relation with audit fees, whereas liquidity ratio and loss incurred in last 5 years revealed a negative correlation with audit fees by coefficient -3.787 and -16.322, respectively. However, other factors such as gearing ratio, Big4, and non-audit fees did not show any rrelationship with audit fees, in which the Significant for these variables are 0.988, 0.179, and 0.670 respectively. Furthermore, the adjusted $\mathrm{R}$ square was about 0.778 , which means that the audit fees model was able to explain the $79.5 \%$ variance of audit fees.

\subsection{Discussion of the Study's Results :}

The total assets were used as a proxy for auditee size in the current study. According to the results of the linear regression indicate that there is a positive relationship between auditee size and audit fees $(\mathrm{P}=0.000)$. Therefore, the results indicate a significant positive correlation between auditee size and audit fees in the AIM machinery equipment. These results are consistent with Hypothesis 1, which was driven from the studies of Al-Harshani (2008) and $\mathrm{Xu}$ (2011) and expected to find a positive correlation between auditee size measured by total assets and audit fees. The reason for that could be that the larger auditee size in the AIM companies results in large balances and transactions that require more time and effort by the auditors in the audit service that leads, in turn, to increased audit fees. The results agree with the findings of some prior researchers, including a British study by Chan et al. (1993) who found that auditee size measured by total assets had a significant positive correlation with audit fees. Three proxies were employed in this study to measure auditee risk, namely, liquidity ratio, gearing ratio, and loss incurred. The results of the multiple linear regression indicated that loss incurred in last 5 years has a negative correlation with audit fees (in which $\mathrm{P}=0.000$ ). Therefore, the result provides evidence that the machinery equipment companies have healthy financial conditions. Meanwhile, the two other measures of auditee risk, liquidity and gearing ratio, were not found to offer strong evidence regarding the effect of auditee risk on the variation of audit fees. This might mean that market-based measures do not provide a better view of the clients' operations. Hence, auditee size does not seem to be high in companies listed in the AIM, despite the fact that AIM companies are risky companies by nature. Therefore, the study has found that there is a negative relationship between auditee 
risk and audit fees in the AIM machinery equipment. The study's finding is consistent with the results of prior researchers who conducted research in different markets, such as Simunic (1980) in the US, Chan et al. (1993) in the UK, and Xu (2011) in China. Meanwhile, this result is not in line with studies from Australia by Zhang and Myrteza (1996), in Jordan by Joshi and AlBastaki (2000), the US by Francis (1984), and Kuwait by Al-Harshani (2008), who all found a significant positive correlation between auditee risk and audit fees, and addressed auditee risk as an important factor that effects the determination of audit fees. Auditee complexity is about the extent of the audit task. Auditee complexity has been identified by Mellett et al. (2007) as one of the factors that has a potential effect on the variation of audit fees. This research has followed the study of Francis (1984) and used two proxies to measure auditee complexity, namely, the number of corporate subsidiaries and account receivable/total assets ratio. The results of the multiple linear regression also present a significant positive relationship between the number of subsidiaries $(P=0.000)$ and the ratio of accounts/total assets $(P=0.002)$ with audit fees. These results can be illustrated by the fact that the level of complexity in the activities that the AIM machinery equipment companies have leads to increase the audit fees. Hence, the study hypothesis regarding the association between auditee complexity and audit fees is proven and the variation of audit fees for the machinery equipment companies is significantly affected by auditee complexity. The findings were therefore consistent with the results of studies conducted by Brinn et al. (1992) in the UK, Hay et al. (2006) in New Zealand, Naser and Nuseibeh (2008) in Jordon, and Thinggaard and Kiertzner (2008) in Denmark, who found that auditee complexity has a significant impact on determining audit fees. However, these results were inconsistent with the findings of Zhang and Myrteza (1996), and Ahmed and Goyal (2005), who found a negative correlation between auditee complexity and audit fees. Auditor size in this study was assumed to be one of the factors that has a positive impact on the variation of audit fees in the AIM machinery equipment companies. Auditor size was measured by the audit firm's brand name and whether it was one of the Big4 international audit firms or not. This is due to the important role of the Big4 audit companies in charging their clients higher audit fees than the local firms because of the audit quality that they provide and the brand name that they have (Boo \& Sharma, 2008). The study has found that from the 23 machinery equipment companies in the study's sample, 8 of these were assigned one of the Big4 companies to do the audit work. The multiple linear regression did not indicate a relationship between the Big4 and audit fees $(P=0.179)$. Hence, the results of the current research confirm that there was no correlation between auditor size and audit fees, and that the findings do not support Hypothesis 5, which expected to find a positive correlation between auditor size and audit fees. This might show that the audit market in the AIM is not dominated by the Big4 audit firms. Thus, this research failed to identify auditor size or auditor brand name as one of the determinants of audit fees for the machinery equipment companies listed on the AIM.These results are consistent with the outcomes of prior researchers; for example, Al-Harshani (2008) investigated the factors that determine the amount of audit fees in Kuwait and his findings showed that auditor size was not a significant influential factor in determining audit fees. Moreover, the results are in line with the findings of Che-Ahmad and Houghton (1996), who were unsuccessful in finding a relationship between auditor size and audit fees in the medium-sized companies in the UK, reporting that there was no price premium paid to the auditor within the companies listed in this sector. However, these results do not agree with the findings of studies conducted in different countries such as Pong and Whittington (1994) in the UK, Langendijk (1997) in the Netherlands, and Choi et al. (2010) in the US, who did not find evidence of a positive correlation between audit fees and auditor size. The 31 ${ }^{\text {st }}$ December financial year-end date, known as the busy season, was involved in the current study as one of the factors affecting audit fees in the AIM machinery equipment companies. This is due to the important role of the busy season in the variation of audit fees in the AIM. The results of the multiple linear regression (see Table (4.3)) was ( $\mathrm{P}=$ 0.012 ). The study has found that there was a positive correlation between audit timing and audit fees. Hence, these results support the theory which suggests that auditors charge their clients higher fees in the busy season. The hypothesis of audit timing in the current study has been built on the outcome of the study by Zhang and Myrteza (1996), who found a positive correlation between audit timing and audit fees. Hence, the outcomes of this study support what was predicted to be found. Despite the fact that there are small numbers of companies listed on the AIM, the busy season takes place in this market and thus the study has recognised audit timing as one of the determinants of audit fees in the AIM. The result is consistent with the results of studies conducted in the UK, such as (Chan et al., 1993; Pong, 2004), who found a significant positive correlation between audit fiscal year-end date and audit fees. Furthermore, an American study by López and Peters (2011) found evidence of a significant positive relationship between the busy season and audit fees. However, the result does not agree with the studies that did not find strong evidence of a positive correlation between audit timing and audit fees, such as (Joshi \& 
Al-Bastaki, 2000; Kasim, 2005). As one of the factors that has been recognised by Chan et al. (1993) and Davis et al.(1993) in the UK to be playing an effective role in the variation of audit fees, this research has taken non-audit fees as a factor that has an influence on determining audit fees in the AIM listed companies. The study hypothesised to find an association between audit and non-audit fees. However, the study found that there was no correlation between audit and non-audit fees, in which the result of the multiple linear regression was $(\mathrm{P}=0.670)$. This might indicate that auditors in the AIM do not reduce the price of audit services in order to provide a consultancy service to their clients. In other words, this means that auditors in the AIM do not extend their business and obtain higher profits through providing wider types of non-audit services for companies listed on the AIM. The research finding therefore does not prove the hypothesis of the correlation between audit and non-audit fees. Hence, non-audit fee is unlikely to be recognised as one of the determinants of audit fees in the AIM. The research result agrees with the findings of Abdel-Khalik (1990), who evaluated the cost of knowledge spillovers from purchasing management advisor services or the nonaudit fees. He discovered that the audit fee was not influenced by purchasing management advisory services from the same audit firm. This result is also compatible with the findings revealed by Barefield, Gaver, and Keefe (1993), who found that there was no correlation between audit and non-audit fees. However, this result does not match the results of previous researchers who found either positive or negative correlations between audit and non-audit fees. Hay et al. (2006), for example, employed data from New Zealand to investigate the relationship between audit and non-audit fees. They found evidence of a relationship between both of the services; hence, they suggest that auditors providing audit and non-audit services simultaneously does not lead to knowledge spillovers. The same results were also obtained by Zhang and Myrteza (1996), who examined the determinants of audit fees in Australia. They discovered a significant positive relationship between audit and non-audit services. The argument of the supporter of such a correlation is based on lowballing or knowledge spillover (Clatworthy et al., 2000; DeAngelo, 1981). Furthermore, studies conducted by (Thinggaard \& Kiertzner, 2008; Whisenant et al., 2003) found a positive relationship between audit and non-audit fees.

\section{Conclusion}

The current study has sought to contribute to the literature by providing new and updated evidence on the determinants of audit fees in one of the sub-markets in the UK, namely the AIM. In particular, the study focused on a sector listed on the UK AIM : machinery equipment. The importance of this study has risen from evaluating the determinants of audit fees in a dissimilar sector, market and different regularity frameworks from those studies which investigated the determinants of audit fees within the companies listed on the main markets in the UK such as (Beattie \& Fearnley, 2002; Chan et al., 1993; M. Clatworthy et al., 2000). The study has proven that auditee size, auditee complexity, and audit timing are the most influencing factors on the variation of audit fees in the AIM machinery equipment, in which those variables featured a significant positive correlation with audit fees. The main finding of this research is that auditee size has been found to have a strong positive relationship with audit fees; hence, it is considered one of the major determinants of audit fees. This could indicate that audit work for large companies in the AIM machinery equipment companies involves more effort and investigation in complicated financial statements. Moreover, auditors in the AIM might increase the audit time in order to evaluate the effectiveness of the internal control system and risk management resulting from the role of the auditor in reviewing company transactions and the internal control system (Beattie \& Fearnley, 2002). This result is compatible with the findings of (Stewart \& Munro, 2007; Yaacob \& Che-Ahmad, 2012). Furthermore, auditee complexity has been found, as hypothesised, to have a positive relationship with audit fees. This could be due to the differences in the level of complexity for the AIM machinery equipment companies in terms of natural activities, business location, or the extent of unusual operations, which would create a need for the auditor to do more testing that accordingly leads to increase the audit fees. This result is in line with the results that have been reached (Al-Matarneh, 2012; P. Chan et al., 1993; Hay et al., 2006), in the UK, New Zealand, and Jordan, respectively. The study has also revealed that audit timing is an important factor that affects the variation of audit fees. The significant correlation of audit timing with audit fees might mean that the machinery equipment companies in AIM are subject to high audit fees in their busy season, or financial year-end date. This outcome is therefore similar to (Pong, 2004; Zhang \& Myrteza, 1996). However, the variable of auditee risk has been found to have a negative relationship with audit fees in the AIM in this study, despite prior researchers such as Pong et al., (2007) having confirmed that auditee risk is one of the significant factors that has an impact on audit fees. Hence, auditee risk was not recognised as a significant determinant of audit fees in this study, which might mean that auditee risk in the AIM would require in-depth investigations by others to examine its effect on audit fees. This finding is consistent with (Simunic, 1980; Xu, 2011). In continuing 
to provide answers to the research questions, the result related to the relationship of auditor size with audit fees was that there was no association between auditor size and audit fees. The reason for that could be explained by the fact that the AIM machinery equipment companies are less likely to deal with the Big4, who provide a high-quality auditing service. This finding, therefore, agrees with the results of (Che-Ahmad \& Houghton, 1996; Francis, 2004). Unlike prior studies, the current research has found that there was no correlation between audit and non-audit fees. The reason behind this non-association could be because the auditors in the AIM do not exploit the poor financial conditions of the companies by taking advantage through providing consultancy services. This result was also reached by (Hay et al., 2006; Whisenant et al., 2003). Hence, nonaudit fee does not appear to be a factor affecting audit fees in the AIM machinery equipment. During this investigation into the factors affecting the variation of audit fees, a number of areas for improvement have been highlighted. One such area is that the AIM should make sure that the auditors are charging appropriate fees for the companies listed on the AIM, because of the significant role of audit fees in the independence of the auditor. This is especially important since this submarket is growing and attention towards it has increased in recent years (Otieno \& Jeffrey, 2007). Given that the current study adds new dimensions to the literature by providing empirical evidence on the determinants of audit fees in the AIM, it also had several limitations. Difficulties of finding data presented one of the significant challenges in this study in terms of the sample selection process, as the financial statements of the AIM listed companies did not include all the data related to the research analysis. Moreover, avoiding choosing primary data was another challenge in this study because it is outside the scope of this investigation. Hence, the study does not include the factors that have been proven to have a significant effect on audit fees as they required collecting data, such as competition among audit firms and industry specialisation, through questionnaires.This research might be the gateway for several opportunities for future studies on this topic in the AIM. For instance, while this study was concentrated on one sector, a future study could compare the determinants of audit fees between two or more sectors or industries from the AIM. Furthermore, future research might make use of primary data through employing questionnaires or interviews with the audit firms and the auditee to collect data for some of the study's variables. Moreover, this study did not take the impact of the economic fluctuations on changes in audit fees into account. Hence, a future study may examine the variation of audit fees in the AIM in the three economic periods of pre-, during, and post- (the recent) financial crisis. A future study could also investigate the effect of the political dimensions on companies listed in the public sector.

\section{References}

1. Abdel-Khalik, A. R. (1990). The jointness of audit fees and demand for MAS : A self-selection analysis.

2. Abidin, S., Beattie, V., \& Goodacre, A. (2010). Audit market structure, fees and choice in a period of structural change : Evidence from the UK-1998-2003. The British Accounting Review, 42(3), 187-206.

3. Ahmed, K., \& Goyal, M. K. (2005). A comparative study of pricing of audit services in emerging economies. International Journal of Auditing, 9(2), 103116.

4. Al-Harshani, M. O. (2008). The pricing of audit services : evidence from Kuwait. Managerial Auditing Journal, 23(7), 685-696.

5. Al-Matarneh, G. F. (2012). The pricing of audit services : Evidence from Jordan. International Business Research, 5(3), 114.

6. Alexeyeva, I. (2012). Effect of different economic conditions on audit and non-audit fees : Evidence from Sweden.

7. Barefield, R. M., Gaver, J. J., \& Keefe, T. B. O. (1993). Additional evidence on the economics of attest : Extending results from the audit market to the market for compilations and reviews. Auditing, 12(1), 76.

8. Barkess, L., \& Simnett, R. (1994). The provision of other services by auditors : Independence and pricing issues. Accounting and Business Research, 24(94), 99108.

9. Beattie, V., \& Fearnley, S. (2002). Auditor independence and non-audit services : A literature review. Institute of Chartered Accountants in England and Wales, London.

10. Behn, B. K., Choi, J.-H., \& Kang, T. (2008). Audit quality and properties of analyst earnings forecasts. The Accounting Review, 83(2), 327-349.

11. Berenson, M., Levine, D., Szabat, K. A., \& Krehbiel, T. C. (2012). Basic business statistics : Concepts and applications. Pearson higher education AU.

12. Boo, E., \& Sharma, D. (2008). Effect of regulatory oversight on the association between internal governance characteristics and audit fees. Accounting \& Finance, 48(1), 51-71.

13. Brinn, T., Peel, M. J., \& Roberts, R. (1992). Determinants of the External Audit Fee of UK Unquoted Companies-Some New Evidence. Management Research News, 15(8), 14-17.

14. Carson, E., \& Fargher, N. (2007). Note on audit fee premiums to client size and industry specialization. Accounting \& Finance, 47(3), 423-446.

15. Chan, K. H., Lin, K. Z., \& Zhang, F. (2007). On 
the association between changes in corporate ownership and changes in auditor quality in a transitional economy. Journal of International Accounting Research, 6(1), 19-36.

16. Chan, P., Ezzamel, M., \& Gwilliam, D. (1993). Determinants of audit fees for quoted UK companies. Journal of Business Finance \& Accounting, 20(6), 765 786.

17. Che-Ahmad, A., \& Houghton, K. A. (1996). Audit fee premiums of big eight firms : Evidence from the market for medium-size UK auditees. Journal of International Accounting, Auditing and Taxation, 5(1), 53-72.

18. Choi, J.-H., Kim, J.-B., \& Zang, Y. (2010). Do abnormally high audit fees impair audit quality? Auditing : A Journal of Practice \& Theory, 29(2), 115140.

19. Clatworthy, M. A., Mellett, H. J., \& Peel, M. J. (2002). The market for external audit services in the public sector : An empirical analysis of NHS trusts. Journal of Business Finance \& Accounting, 29(9-10), 1399-1439.

20. Clatworthy, M. A., \& Peel, M. J. (2007). The effect of corporate status on external audit fees : Evidence from the UK. Journal of Business Finance \& Accounting, 34(12), 169-201.

21. Clatworthy, M., Mellett, H., \& Peel, M. (2000). Developments : External Audit Fee Levels in NHS Trusts. Public Money and Management, 20(1), 63-68.

22. Cohen, J., Gaynor, L. M., Krishnamoorthy, G., \& Wright, A. M. (2007). Auditor communications with the audit committee and the board of directors : Policy recommendations and opportunities for future research. Accounting Horizons, 21(2), 165-187.

23. Colombelli, A. (2010). Alternative investment market : a way to promote entrepreneurship. Journal of Industry, Competition and Trade, 10(3-4), 253-274.

24. Davis, L. R., Ricchiute, D. N., \& Trompeter, G. (1993). Audit effort, audit fees, and the provision of nonaudit services to audit clients. Accounting Review, 135-150.

25. Davison, A. G., Stening, B. W., \& Wai, W. T. (1984). Auditor concentration and the impact of interlocking directorates. Journal of Accounting Research, 313-317. 26. DeAngelo, L. E. (1981). Auditor independence, "low balling", and disclosure regulation. Journal of Accounting and Economics, 3(2), 113-127. http : //doi.org/10.1016/0165-4101(81)90009-4

27. Dopuch, N., \& Simunic, D. (1980). The nature of competition in the auditing profession : a descriptive and normative view. Regulation and the Accounting Profession, 34(2), 283-289.

28. Firth, M. (2002). Auditor-provided consultancy services and their associations with audit fees and audit opinions. Journal of Business Finance \& Accounting, 29(5-6), 661-693.
29. Francis, J. R. (1984). The effect of audit firm size on audit prices : A study of the Australian market. Journal of Accounting and Economics, 6(2), 133-151.

30. Francis, J. R. (2004). What do we know about audit quality? The British Accounting Review, 36(4), 345-368.

31. Gist, W. E. (1992). Explaining variability in external audit fees. Accounting and Business Research, 23(89), 79-84.

32. Gujarati, D. N., \& Porter, D. C. (2003). Basic Econometrics. 4th. New York: McGraw-Hill.

33. Che Ahmad, A., Haniffa, R., Houghton, K. A., \& Zalina Mohamad Yusof, N. (2006). The Malaysian market for audit services : ethnicity, multinational companies and auditor choice. Managerial Auditing Journal, 21(7), 702-723.

34. Hay, D. C., Knechel, W. R., \& Wong, N. (2006). Audit fees : A Meta-analysis of the effect of supply and demand attributes. Contemporary Accounting Research, 23(1), 141-191.

35. Hogan, C. E., \& Jeter, D. C. (1999). Industry specialization by auditors. Auditing : A Journal of Practice \& Theory, 18(1), 1-17.

36. ICAEW. (2012). ICAEW helps companies meet new auditor remuneration reporting requirements. http : //doi.org/http : //www.icaew.com/en/abouticaew/newsroom/press-releases/2012-press-releases/ ica ew -helps-companies-meet-new-auditorremuneration-reporting-requirements

37. Jensen, M. C., \& Meckling, W. H. (1976). Theory of the firm : Managerial behavior, agency costs and ownership structure. Journal of Financial Economics, 3(4), 305-360.

38. Joshi, P. L., \& Al-Bastaki, H. (2000). Determinants of audit fees : evidence from the companies listed in Bahrain. International Journal of Auditing, 4(2), 129138.

39. Kasim, M. N. (2005). THE DETERMINANTS OF AUDIT FEES FOR SMES IN MALAYSIA AND IMPLICATIONS OF MIA GUIDLINES. Universiti Sains Malaysia.

40. Langendijk, H. (1997). The market for audit services in the Netherlands. European Accounting Review, 6(2), 253-264.

41. López, D. M., \& Peters, G. F. (2011). Auditor workload compression and busy season auditor switching. Accounting Horizons, 25(2), 357-380.

42. Mallin, C., \& Ow-Yong, K. (2012). The UK alternative investment market-ethical dimensions. In Entrepreneurship, Governance and Ethics (pp. 223-239). Springer.

43. Mellett, H., Peel, M. J., \& Karbhari, Y. (2007). Audit fee determinants in the UK university sector. Financial Accountability \& Management, 23(2), 155-188.

44. Millichamp, A. H., \& Taylor, M. (2008). Auditing and Investigation. Ceteris Publishers, Enugu. 
45. Naser, K., \& Nuseibeh, R. (2008). Determinants of audit fees : empirical evidence from an emerging economy. International Journal of Commerce and Management, 17(3), 239-254.

46. Neter, J., Wasserman, W., \& Whitmore, G. A. (1993). Applied Statistics. 4th Edt. Boston : Allyn and Bacon. 47. Otieno, R., \& Jeffrey, M. (2007). A decade of Alternative Investment Market (AIM)-but little impact on the UK apparel sector. Journal of Fashion Marketing and Management : An International Journal, 11(3), 441444.

48. Palmrose, Z.-V. (1986). Audit fees and auditor size : Further evidence. Journal of Accounting Research, 97110.

49. Pong, C., Gonthier-Besacier, N., \& Schatt, A. (2007). Determinants of audit fees for French quoted firms. Managerial Auditing Journal, 22(2), 139-160.

50. Pong, C. K. M. (2004). A descriptive analysis of audit price changes in the UK 1991-95. European Accounting Review, 13(1), 161-178.

51. Pong, C. M., \& Whittington, G. (1994). The determinants of audit fees : Some empirical models. Journal of Business Finance \& Accounting, 21(8), 10711095.

52. Rezaee, Z. (2009). Corporate governance and ethics. John Wiley \& Sons.

53. Rick, H., Dassen, R., Schilder, A., \& Wallage, P. (2005). Principles of Auditing : An Introduction to International Standards on Auditing. London : Prentice Hall.

54. Sandra, W. M. H., \& Patrick, P. H. N. (1993). The determinants of Audit Fees in Hong Kong : An Empirical Study'. Asian Review of Accounting, 4 (2), 3250

55. Simon, D. T., \& Francis, J. R. (1988). The effects of auditor change on audit fees : Tests of price cutting and price recovery. Accounting Review, 255-269.

56. Simunic, D. A. (1980). The pricing of audit services : Theory and evidence. Journal of Accounting Research, 161-190.

57. Simunic, D. A. (1984). Auditing, consulting, and auditor independence. Journal of Accounting Research, 22(2), 679-702.

58. Soltani, B. (2007). Auditing : An international approach. pearson education.

59. Stewart, J., \& Munro, L. (2007). The impact of audit committee existence and audit committee meeting frequency on the external audit : Perceptions of Australian auditors. International Journal of Auditing, 11(1), 51-69.

60. Sweeney, J. T., \& Summers, S. L. (2002). The effect of the busy season workload on public accountants' job burnout. Behavioral Research in Accounting, 14(1), 223245.

61. Thinggaard, F., \& Kiertzner, L. (2008). Determinants of audit fees : Evidence from a small capital market with a joint audit requirement. International Journal of Auditing, 12(2), 141-158.

62. Van Caneghem, T. (2010). Audit pricing and the Big4 fee premium : evidence from Belgium. Managerial Auditing Journal, 25(2), 122-139.

63. Vu, D. H. T. (2012). Determinants of audit fees for Swedish listed non-financial firms in NASDAQ OMX Stockholm.

64. Whisenant, S., Sankaraguruswamy, S., \& Raghunandan, K. (2003). Evidence on the joint determination of audit and non-audit fees. Journal of Accounting Research, 41(4), 721-744.

65. Whittred, G., \& Zimmer, I. (1984). Timeliness of financial reporting and financial distress. Accounting Review, 287-295.

66. Willmott, H. (1986). Organising the profession : a theoretical and historical examination of the development of the major accountancy bodies in the UK. Accounting, Organizations and Society, 11(6), 555580.

67. Xu, Y. (2011). The Determinants of Audit Fees : An Empirical Study of China's listed companies.

68. Yaacob, N. M., \& Che-Ahmad, A. (2012). Audit fees after IFRS adoption : Evidence from Malaysia. Eurasian Business Review, 2(1), 31-46.

69. Zhang, M.-W., \& Myrteza, S. (1996). The determinants of audit fees : Australian perspective. Asian Review of Accounting, 4(1), 81-97. 